\title{
SYMBIOSIS OF MODERNISATION AND NATIONAL IDENTITY IN THE LEGACY OF THE “BALTARS” (BALTIC ART) PORCELAIN PAINTING WORKSHOP, 1924-1930
}

\begin{abstract}
Summary. This article is dedicated to the "Baltars" collective porcelain painting workshop (1924-1930), founded in Riga, Latvia by three modernist artists: painters Romans Suta (1896-1944) and Aleksandra Beḷcova (18921981) and graphic artist Sigismunds Vidbergs (1890-1970).The "Baltars" phenomenon is significant because of the innovations that the artists brought to the landscape of Latvian porcelain manufacturing and its exhibition activities in the 1920s and the early 1930s, both local and in the Baltic Sea region-Lithuania, Estonia, and Sweden. The article investigates "Baltars" foundation and closure, artistic activities of the company, its attempts to enter the international art and trade scene, and its accomplishments. Special attention is paid to the amalgamation of modernisation, nationalism, and state-building manifested in their paintings on porcelain. Due to the present growing interest in porcelain art in Latvia, triggered by numerous exhibitions and publications, discourse on the "Baltars" phenomenon has become topical.
\end{abstract}

Keywords: "Baltars" workshop, Riga, porcelain painting, revolutionary propaganda porcelain, national identity, international exhibitions.

Art is a nation's most precious heritage. For it is in our works of art that we reveal to ourselves and to others the inner version which guides us as a nation. And where there is no vision, the people perish.

President of the United States Lyndon B. Johnson ${ }^{1}$

Every artist, in a general sense, is a cosmopolitan, and it has always been a challenging and breathtaking experience to glance over "the fence" to see what their fellows in the professional field in the neighbourhood or even distant countries are doing. However, there are crucial times in history when assertion of self-identity and identity of the nation plays a key role and finds explicit reflection in art. Sometimes, as is the case with the "Baltars" porcelain-painting workshop, it evolves into a peculiar symbiosis of the modernist style and nationalist content. In the mid-to-late 1920s, it was a general tendency for nationalist interpretations to live in symbiosis with the modernist trends of Cubism and Art Deco, although in each country the exact manifestation differs. This includes selection of themes, proportions, rhythm, colour schemes, and application of geometric ornaments.
What does the name of the "Baltars" porcelain-painting workshop mean to a non-Latvian reader? It is highly probable that the majority have never heard it before, although it is essential in the history of Latvian art. Today, the outstanding artistic legacy of the company is on the State Cultural Heritage list as one of the nation's unique and irreplaceable treasures. The "Baltars" phenomenon is significant because of the innovations that the artists brought to the landscape of Latvian porcelain manufacturing and its exhibition activities in the 1920s and the 1930s, both local and in the Baltic Sea region-Lithuania, Estonia, and Sweden. The exhibitions were held in more geographically distant countries, too. The logo of the company is used in three colours: it is a black, red, or green triangle with the word BALTARS (from the Latin Ars Baltica: Baltic Art) and the artist's signature. Three Latvian artists-Romans Suta (1896-1944), 
Aleksandra Bel̦cova (1892-1981), and Sigismunds Vidbergs (1890-1970)_took up the challenge to promote modern porcelain production, step over local art borders, and encompass Lithuania and Estonia in their creative endeavours. The graphic design of the logo most probably means three artists and three independent Baltic countries (Fig. 1-2).

Despite the enormous popularity that "Baltars" enjoys today and a number of art historians who have analysed its activities over time, numerous questions regarding the foundation and closure of the workshop, exhibitions, and many other related issues have not been discussed in depth, so it is essential to revise this information and add new facts to it. ${ }^{2}$

Unfortunately, within the allotted limits of this article, it is impossible to illustrate all the many-sided aspects of the "Baltars" phenomenon. Therefore, the article discusses the basic issues. First, it aims to show that stereotypical viewpoints on some issues regarding the company, which have dominated

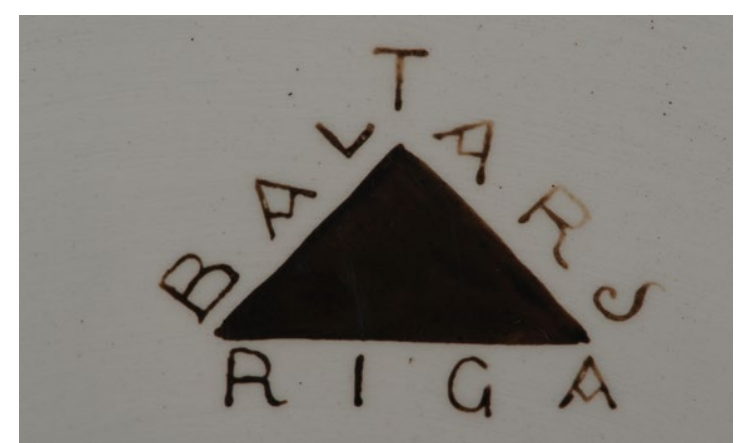

Fig. 2. "Baltars" $\log o$

literature for years, and legends about it that have originated in the course of time must be discussed and revised. Second, another question of interest is the specific amalgamation of modernisation, nationalism, and state-building manifested through the paintings on "Baltars" porcelain ware. In fact, the thematic range of their paintings is much broader, including the artists' impressions gathered in Italy, France, and Spain, and the exotic motives of the Philippines, Africa, the far North, etc.

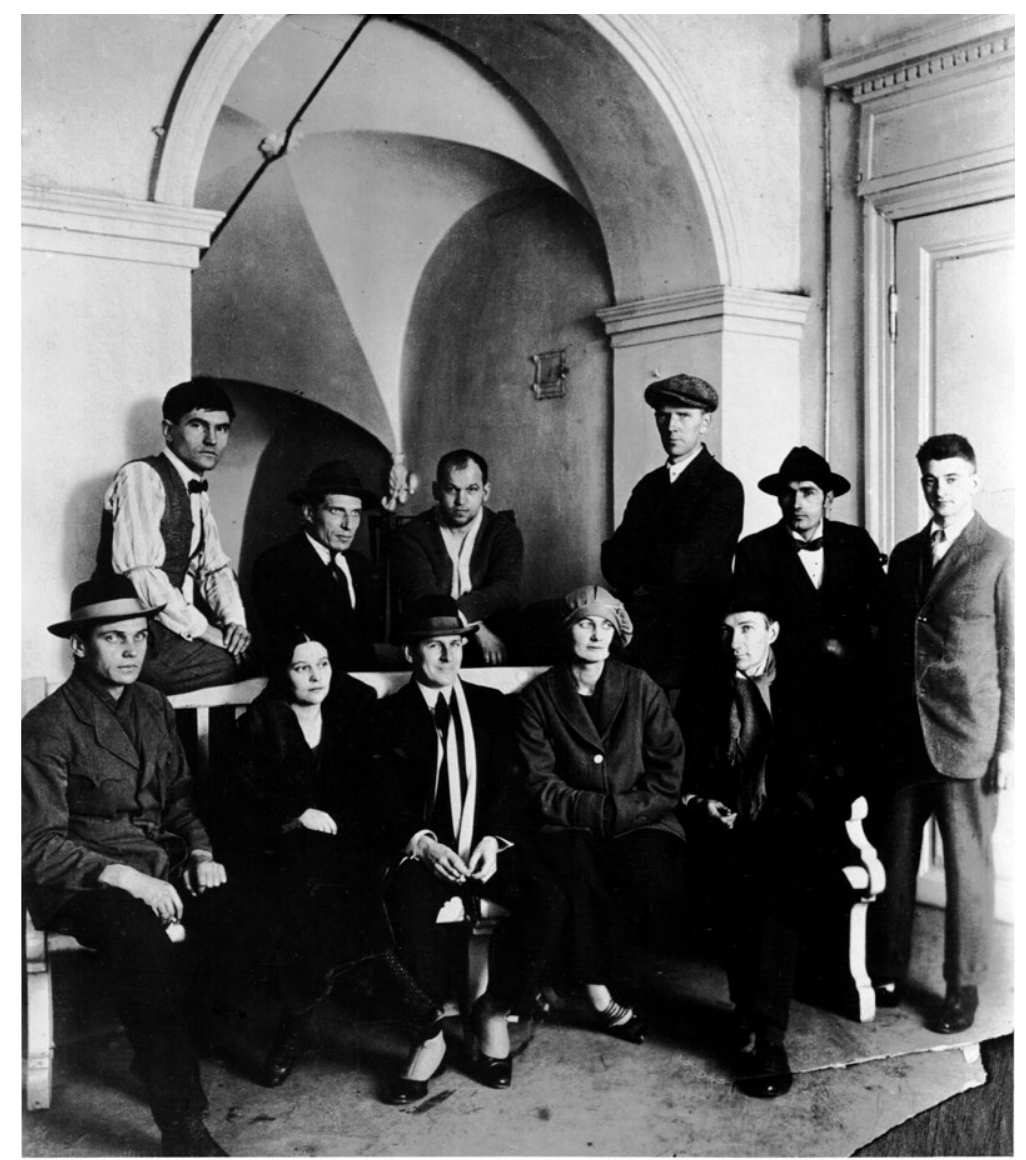

Fig. 1. Riga Artists Group. 1923. First row, second from the left: Aleksandra Belcova, third from the left: Sigismunds Vidbergs. Second row, third from the left: Romans Suta 
In 1923, Latvia celebrated the fifth anniversary of independence. After years of suffering and devastation caused by the First World War, refugees were gradually returning to their homeland. In 1918, young avant-garde artist Romans Suta, after graduating from the Penza Art School in Russia, returned to Latvia. In 1919, by his invitation, Aleksandra Belıcova, his school-time girlfriend who was highly artisticminded and no less creative, moved to Riga, too. Sigismunds Vidbergs, graduate of the Baron Stieglitz Central School of Technical Design in St. Petersburg who had specialised in glass art and at the time was already a well-known graphic artist in Petrograd, returned to Riga in 1921. They were all young and strived not only to show their creative and artistic capacities but also to radically change the then stagnating academic situation in the tranquil Latvian art scene. Alongside with the foundation of the independent state and the end of the subsequent War of Independence, new opportunities emerged. The young artists based their creative work on maximalist attitudes characteristic of youth, their desire for experimentation, and talent. They saw a possibility to implement various artistic avant-garde ideas and unlimited expressions of free art that prevailed at exhibitions in Russia as well as in European art centres, especially Paris. Futurism, Cubism, Constructivism, Suprematism - all these various styles and directions as well as remarkable cultural personalities were the source of inspiration and a reference point for the creative work of the three Latvian artists.

Despite the damages of the war, the people's desire to work for their own well-being was growing. Politically, Latvia was involved in the League of Nations, where diplomats were discussing topical questions, such as inter-state conventions and possible strengthening of the unity of the Baltic States. In the Saeima (the parliament of Latvia), party factions were looking for solutions to the problems of the state, but at the same time, they kept on fighting each other. Particularly strong and angry, holding one third of the seats, was the Social Democratic Workers' Party, favoured by the members of the Riga Artists' Group, including Suta, Bel̦cova, and Vidbergs.

Economic life, judging by publications in the press, was becoming more active. Newspaper and magazine pages were full of flashy advertisements of goods, household services, and entertainment. The Solomon Circus promised grand shows, theatres-stage performances, and cinemas, including the newly opened "Splendid Palace" - the trendiest and the most stylish new building in Riga or, as the weekly called it, "a recess for relaxation and cosiness"-promoted foreign films. Cafes, restaurants, and Riga's most elegant dance hall "Trokadero" on Brivibas Street invited visitors to lavishly spend their money and enjoy life. ${ }^{3}$ Publishing has also become lively: there were plenty of books, some artist monographs, and newspapers and magazines of various profiles. Contacts for potential international exhibitions of Latvian industrial and artistic products were multiplying. Eduards Bīriņš, Consul General of the Republic of Latvia to the United Kingdom, visited the Grand Exhibition of the British Empire, and it was discussed by the Latvian press. ${ }^{4}$ Latvia displayed its products in a stand in the international co-operation exhibition in Ghent. ${ }^{5}$ While abroad, Latvians had much to see, think about, learn, absorb, and try to make the best of it all.

The true situation in applied art becomes clear if we read the press articles about the organisation and results of the Latvian General Applied Art Exhibition (1924), organised by ethnographer and publicist Eduards Paegle. Art historian Jānis Siliņš criticised the general negative tendency that prevailed among the exhibition participants: they considered that their copies of ethnographic artefacts had to be considered as novel decorative art objects and, to his mind, did not contribute to the development of art. In his view, "although, in the European context, Latvia could boast of its fine art, in industrial and applied art we have not done enough to disseminate the knowledge about our culture abroad, although many possibilities exist in this respect. At present, this issue has become extremely topical as we are on the eve of the 1925 World Applied Art Exhibition in Paris. We have to do everything to ensure that our best artists and industry, albeit on a small scale but in a respectable manner, can represent Latvia." ${ }^{6}$

Romans Suta ardently participated in the discussions about the perspectives and future direction 
of Latvian applied art. He was never diplomatic, on the contrary, always took the position of a confident champion, throwing categorical and ruthless judgments at his opponents. In his article, Suta ironically admits: "At present, we live in the time of nationalist hypertrophy. What else could be national? Alcohol, clothes' irons, soaps, piglets. [...] As we have had no tradition or basic principle in any plastic arts before, and we still have none, we are returning to preancestor ornaments."

He ironically refers to the obsessive application of Latvian ornaments as a national "culture of mittens" that is supported by its "jolly troubadours who keep ticking checkboxes". According to Suta, the General Exhibition resembles a flea market. He comments: "It is a bad idea to travel to Paris in 1925 and bring this weak surrogate of applied art with us. All the more so since the rules of the exhibition exclude compilations of already existing motifs." 8

Applied art, including ceramics, required urgent improvements. In pottery, vases, pots, and plates designed by artists Ansis Cīrulis and Pēteris Šteinbergs were popular and sold well. However, as Rūdolfs Pelše, an experienced ceramicist and professor, stated, nobody had seriously studied ceramic materials and technology, and the articles made by the artists were quite incomplete. They were deformed, water-permeable; their colours smudged, glazes cracked. ${ }^{9}$ Technology had to be improved. Pelše assumed the leadership, and already in 1923, under the aegis of the Art Academy of Latvia, a laboratory for research of ceramic materials and technologies opened its doors. In 1924, it became a ceramics workshop and accepted its first students, although results of their creative efforts were visible only in subsequent years and required much experimentation and hard work.

In the 1920s, the two major Riga porcelain factories, owned by Kuznetsov and Jessen-entrepreneurs of Russian and German origin, respectively-resumed their work with new vigour. Yet there were many questions about the output of these factories. They used pre-war models and patterns of Russian and Western European porcelain ware and sold almost all their produce abroad. Pelše comments:
It is impossible to assert that the Kuznetsov crockery factory is a Latvian enterprise, because its faience and porcelain are nothing more than Russian-style market products. Despite the solid support that he has received from the Latvian government for the renovation of his factory, Kuznetsov still adheres to the old traditions and diligently guards [his factory production] against Latvian impact, and he keeps explaining that Latvia is still a very young country and it is too early to think of its peculiar national colouring. Following this philosophy, Kuznetsov, as the only king of earthenware and porcelain in Latvia-taking into account that there is no competition for him in Latvia, Estonia, and Lithuania-exports his crockery even to America, establishes high prices on his own whim and we, may we like it or not, have to pay, because we find no other alternatives. Apart from this, Kuznetsov carefully protects secrets of manufacturing and nobody from the outside is allowed into the factory, although he receives state benefits. ${ }^{10}$

The described situation demonstrates the fact that, in the 1920s, Latvia could be proud neither of the technological quality of its ceramics nor of representational industrial porcelain products of the national style.

In October 1922, Suta travelled to Berlin to visit the Van Diemen Gallery. It held the ambitious First Russian Art Exhibition (Erste Russische Kunstausstellung). It was the first significant representation of Soviet art and ideological stance abroad. For the Soviet state, it was one of the opportunities to win worldwide recognition in art, which was extremely important to it in the political sense. Germany, on the other hand, saw it as a possible solution to ending the country's isolation caused by the war. One of the aims of the exhibition was charity: the money from the sale of artworks was donated to the famine-stricken population of the Volga region. The exposition covered the period from 1905 and included artworks by Russian artists living in the USSR and by those who had already 
emigrated as well as students of the Moscow Higher Artistic Workshop (VHUTEMAS). One hundred and eighty outstanding artists (Alexandre Benois, Wassily Kandinsky, Kazimir Malevich, Ivan Puni, Vladimir Tatlin, Nathan Altman, Nadezhda Udaltsova, Naum Gabo, Gustav Klutsis, Aleksandr Drevin, etc.) exhibited 594 works of art: paintings, graphic pieces, posters, scenography, and sculptures. Apart from this, the exhibition included a vast display of Soviet Russian revolutionary propaganda porcelain created by the artists of the VHUTEMAS workshop and the State Porcelain Factory. ${ }^{11}$ Judging from the catalogue, one hundred and three items-bowls, plates, sugar basins, caskets, figurines, and porcelain toys-were on the show. By that time, these items had already turned into desirable Soviet export products and attracted much-needed foreign currency to Russia. The general impact of the exhibition and especially the colourful display of painted porcelain ware accumulated and charged up Suta's powerful creative impulses, leading him to contemplate about the ways he could synthesise nationalist content with modern stylistics. Vidbergs, in turn, was an acquaintance of Sergey Chekhonin, who was art director at the former Imperial Porcelain Factory in Petrograd. Russian agitation porcelain, its stylistics, technology of production, and artists were all known to Vidbergs. Belcova was in a similar situation. While living in Petrograd, she had studied in Nathan Altman's private studio, whose attempts to paint on porcelain were generally known. Moreover, agitation porcelain was constantly on display in the Kornilov's shop window on Nevsky Prospect.

To the young modernists Suta, Beḷcova, and Vidbergs, the sad state of Latvian ceramic art and porcelain industry was clear. At the time, for two painters and a graphic artist to start a collective ceramic workshop was considered a radical initiative. The field was technically demanding and unfamiliar to them. It was an avant-garde idea to create novel, contemporary forms of ceramic articles and resign from the simple, overused commonplace ethnographic decoration style, which was, in fact, a mere mechanical copying of ornaments. They wanted to raise public awareness and educate its taste by incorporating new ideas from
European modernist paintings and decorative art into the Latvian art scene.

The second precondition for the foundation of "Baltars" was the approaching 1925 Paris International Exhibition of Decorative and Industrial Arts (Exposition internationale des Arts décoratifs et industriels modernes). The Latvian press kept on busily advertising the upcoming exhibition, and several ministries started to draft documents for the occasion. The artists saw an opportunity to receive financial support from the government and show their artworks internationally. The exhibition served as a catalyst that encouraged them to take up the craft of painting on porcelain ware-at the time atypical of Latvian art. They had experience from international exhibitions and were acquainted with the ceramic trends of the time. Another, no less important practical reason to start a ceramics workshop was of financial nature: they could sell porcelain ware easier than canvases and graphic art pieces.

After the First World War, territorial and political changes happened all across Europe. The victory in the War of Independence (1918-1919) made it possible to proclaim independence of the Republic of Latvia. The urgent task of the new state was to make its existence known on the world art scene. Moreover, Latvia received an official invitation to participate in the 1925 Paris International Exhibition of Decorative and Industrial Arts. The 1925 Paris exhibition was the first international show held after the First World War. One of its tasks was to acquaint the "old Europe" with its new neighbours, the new national states. From the Baltic States, only Latvia, after long discussions on all political and organisational levels and a delay in time, finally decided to participate in the show. However, Latvia was not the only newly founded state to take part. Out of its closest neighbours, Soviet Russia and Poland (at that time Latvia had a land border with it) also took part. Participation in the Paris exhibition was supposed to show Latvian cultural identity and accentuate its difference from "others"-both the countries that Latvia was previously territorially and politically included in and the new neighbours. It was seen as propaganda work to promote the country. At the time, such terminology was self-evident 
(nowadays, it brings up some negative connotations of the Soviet regime). Commissioner of the Polish pavilion Jerzy Warchałovski described the general situation: "Our responsibility after the restoration of independence was enormous. The question was: to be or not to be, to influence the world's artistic industrial movement with our immanent special power and national peculiarity or to disappear in the sea of futile efforts." ${ }^{12}$

The initial idea of the three artists was to produce ceramic ware. Most probably in the first half of 1924, the first firing kiln was built and the artists started their experimentations with earthenware crockery. Unfortunately, they were unsuccessful. Due to a mistake in kiln construction, its first output of modern items made in a constructive style perished, and the house almost caught fire. ${ }^{13}$ The artists decided to start anew and make the process much easier. They decided to decorate ready-made porcelain ware that they bought in Riga and porcelain enterprises in Czechoslovakia and Germany.

There were also practical and technological reasons to use porcelain. Making and firing earthenware crockery was much more labour-consuming and expensive and had a higher dropout rate than firing finished decorated porcelain ware. Clay articles must undergo firing at 1,200 degrees Celsius, but for porcelain, 800-850 degrees are enough. Of the three artists, it turned out that only Vidbergs, who had studied glass working, was more or less experienced in applied art, so he could feel more confident than others. To reach the highest possible quality of porcelain painting, the artists invited Dmitry Abrosimov to join the group. Previously he had worked as a porcelain decorator at several porcelain enterprises, including the Dulev and Riga factories owned by the Kuznetsov family. He was one of the best technology specialists as he had also mastered his experience at the Imperial Porcelain Manufactory in St. Petersburg. The first press publication that provides some information on "Baltars" activities asserts that, already by the end of 1924, Suta and Belcova had started painting on porcelain. On November 16, the Riga Artists' Group and the Polish Artists Association "Blok" opened their joint exhibition at the Riga City Museum, which was comprised of fourteen porcelain plates and cups decorated by Suta and Belcova. ${ }^{14}$ Consequently, this date can be confirmed as the premiere of "Baltars".

Unfortunately, the official date of "Baltars" birthday remains unclear. Back in 1972, an article published in Zinātñu Akadēmijas Vêstis indicated that the date of the company's foundation is February 1, 1925, when Vidbergs registered the company. ${ }^{15}$ Unfortunately, there is a mistake, as the indicated document in the State Historical Archive of Latvia holds information about employee medical insurance in a joinery company. ${ }^{16}$ Neither an official publication about the registration of "Baltars" by any of the responsible state organisations nor an announcement of the foundation of the company in the state-issued newspaper Valdïbas Vēstnesis have been found.

The porcelain ware painting workshop was opened at 23 Lāčplěša Street in Riga. The artists managed to find a sponsor for their workshop. It was Austra Ozolina-Krauze, a wealthy entrepreneur, publicist, and, as we know today, double spy working for both Germany and Soviet Russia. ${ }^{17}$ Today it is impossible to tell the exact time when Ozolina-Krauze became involved in the activities of the "Baltars" workshop. There are no facts about her financial contribution, but it is definite that she allotted the basement of her house at 23 Lāčplēša Street for the workshop. ${ }^{18}$

Researchers generally hold to the view that Suta's talent of persuasiveness was responsible for most of the fundraising, but the reality might have been quite different. It seems that at the beginning and the end of the workshop's existence, the role of Belcova was more important than considered. Private letters show that there was a close friendly bond between Bel̦cova and Ozoliņa-Krauze. Bel̦cova definitely was her authorised person. Many sources prove close financial and business cooperation between them. ${ }^{19}$

To make the work more efficient, the company artists-Suta, Belcova, Vidbergs, and the specialist in porcelain technology Abrosimov with his familymoved into the same house.

Besides oil painting, graphic art, organisation of exhibitions, illustration of books, periodicals, and magazines, and other creative activities, the artists also prepared watercolour sketches for porcelain 
ware decoration. Abrosimov transferred these designs to the plates. He also took care of the temperature during firing and checked if colours matched the initial design. Suta and Beḷcova worked out the small details on their own. They preferred overglaze painting to underglaze. The underglaze technique was deviant in colour transitions and not suitable for the artists' intentions as it was unable to provide the richness and saturation of colour that are necessary to create an attractive decorative, constructive, or realistic drawing. Vidbergs used his own graphic illustrations as basic material and drew his ink compositions directly on porcelain.

Their specific artistic style originated from various sources. On the one hand, there were impressions of modernist paintings seen in Russia during their refuge, when, as art students, they had visited many museums and exhibitions of classical and modern art. On the other hand, there were their trips to
Germany and France and their contacts with outstanding Italian, German, and French artists.

In the 1925 Paris exhibition, alongside works of Latvian artisanship, "Baltars" had its own stand on the second floor of the Grand Palais. Despite the small number of exhibits (about thirty-four) and the very disadvantageous space allotted for the display, their painted porcelain ware attracted the attention of professionals of the field. The modern, artistically painted crockery of "Baltars" won public and expert acclaim and resulted in gold and bronze medals awarded to the artists and the company (Fig. 3-4). The voluminous illustrated catalogue of the exhibition holds an image of "Baltars" artworks next to those of Soviet Russian agitprop porcelain. ${ }^{20}$ It is likely that the images for the catalogue were selected by the jury or its authorised representatives. The original photo shows painted porcelain ware by Vidbergs, who won a gold medal (except for the

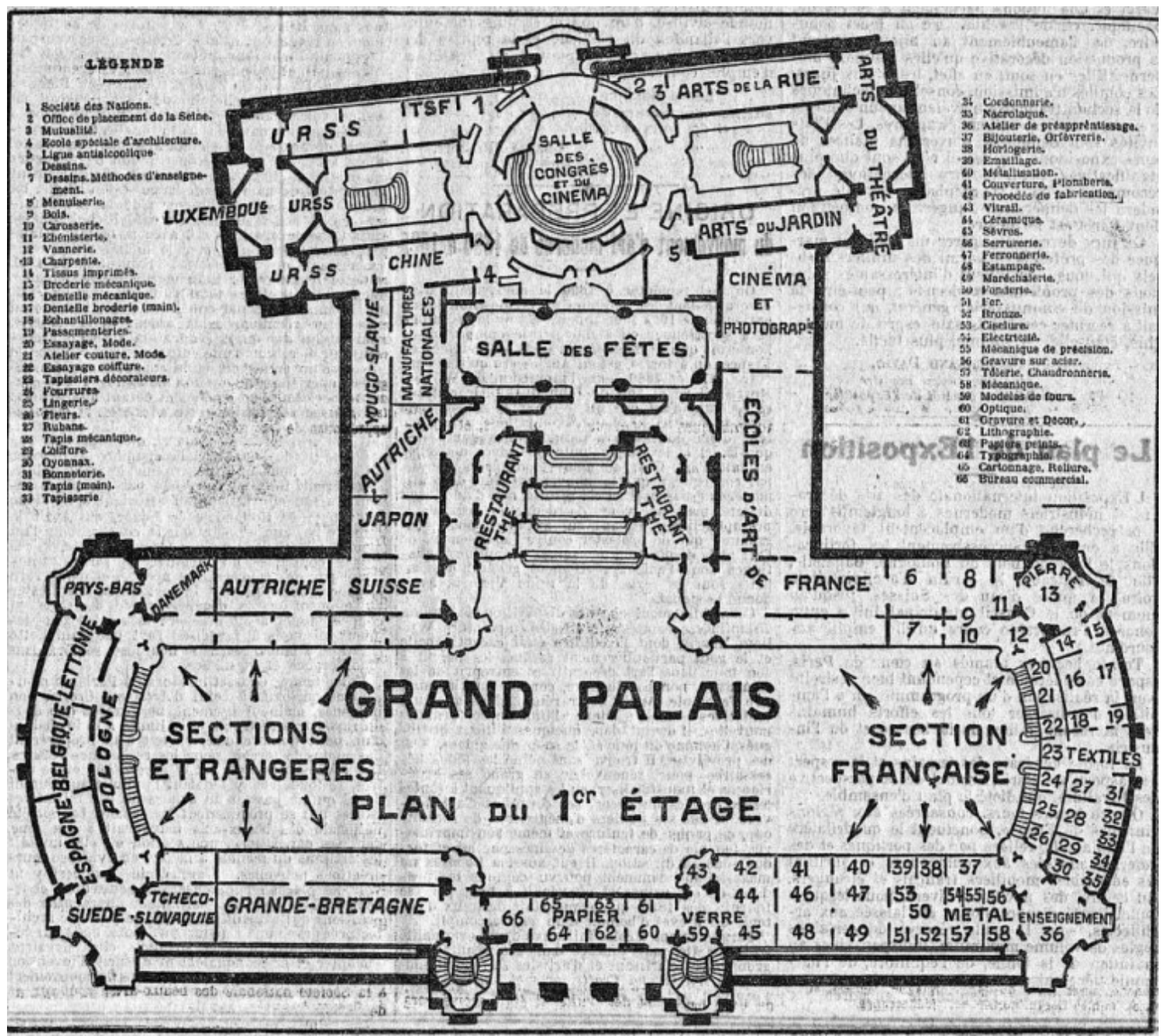

Fig. 3. Plan of the Grand Palais during the Paris International Decorative and Industrial Arts Exhibition. 1925 


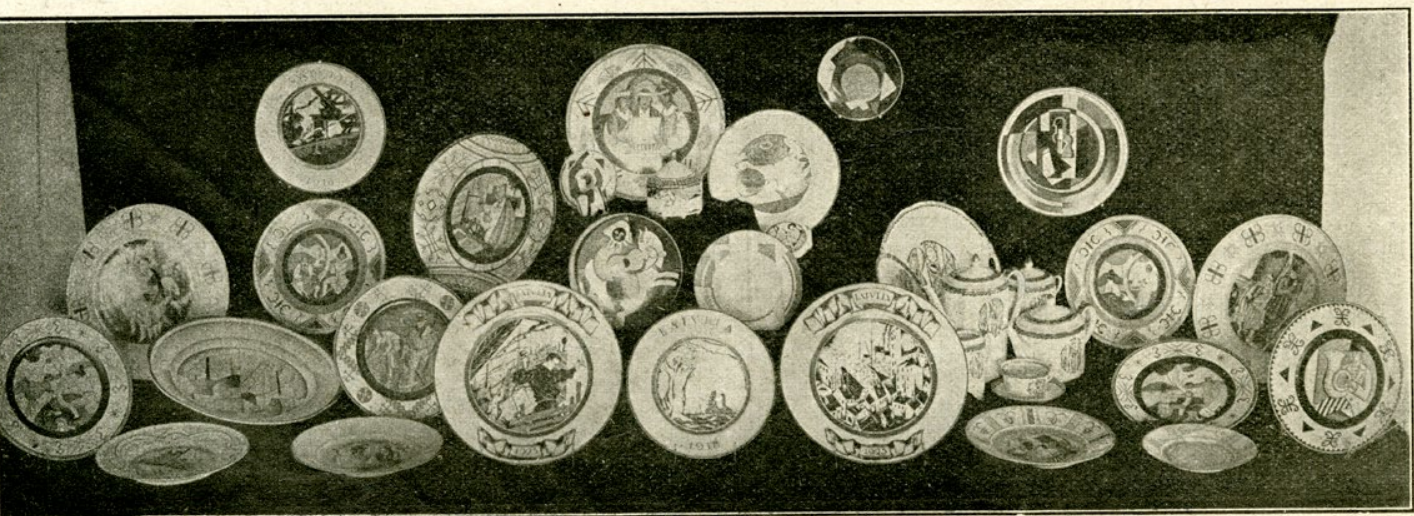

Sabiedribas_ «Baltarss» trauki. Nosūtiti uz lietiškās mākslas izstādi Parizē.

Foto Ricksts, Rigă.

Fig. 4. "Baltars" crockery, sent to the Paris International Decorative and Industrial Arts Exhibition, 1925. Photography by Jānis Rieksts. From: Nedēla, No. 14/15, 1925

plate in the centre of the first row that was created by Erasts Šveics, who worked at "Baltars" episodically).

How did national identity get along with modernisation in the "Baltars" artists' paintings on porcelain? It is possible to characterise this briefly through the following examples from the legacies of each artist.

Suta's designs show his fantasy and imagination. Thematically they are similar to his oil and graphic artworks. He tells stories of rural and urban life, renders historical events, and sometimes, inspired by French artists, creates abstract geometric compositions in the Cubist style.

His compositions on porcelain ware, both realistic or stylised, feature elements from farm life and show the spirit of the people. In fact, the life cycle consists of the three most important events associated with ritual activities - the birth, the wedding, and the funeral, out of which the most important for Suta was the wedding, as it denotes an individual's happy transition from one status to another. ${ }^{21}$ Ancient Latvian weddings were full of songs, dancing, and games and were closely linked to the old folk beliefs and nature. Suta's designs have a common storyline, successively showing the events of becoming a new family: Mìlestība (Love), 1927, Saderināšanās (Engagement), 1927, Precinieki (Giving Away the Bride), 1928, Käzas (The Wedding) 1924-1928, and Pāris (The Couple), 1925-1928.

Regarding construction, designs of wedding and engagement celebrations resemble epic folk style theatrical performances. For example, the plate
Käzas (The Wedding) (Fig. 5) is particularly ambitious in its size and composition. The action takes place in a unified space, encompassing also the outside world that enters through the open door. The window looks out to the town, and the spire of the church tower reminds the onlooker about sacred ceremonial rituals. In fact, these elements are characteristic of almost all Suta's Käzas (The Wedding) plates. It seems like the whole world is participating in the wedding. He arranges the space of the room on several levels. The composition is lively; the improvised festive gate made for the newlyweds, the rhythmically arranged groups of guests, the lines of women ceremoniously bringing the festive mealevery detail works to create an overall impression of excitement and dynamism. The column in a

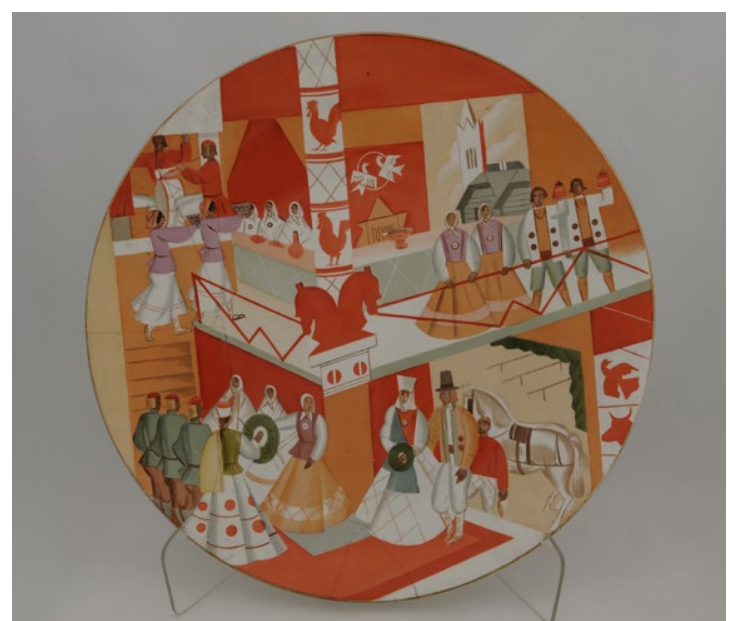

Fig. 5. Romans Suta. Kāzas (Wedding). Plate. 1928. Faience, overglaze painting, gilding, Ø 50, Museum of Decorative Arts and Design collection, DLM/K-1923. Photography by Ritvars Skuja 
pseudo-national style, decorated with sculptured horse heads and stylised roosters, divides the room almost in half. It has two diagonal lines attached to it, forming a balcony. On the first floor, we see longlined tables and groups of celebrating people in folk dresses, and higher, already on the next levelorchestra musicians. Besides the national decorative elements in the centre-the stylised roosters and the horses-there is a romantic token of love in the form of two doves and a ring, an ancient symbol of peace and love, used in Christianity and especially popular at the beginning of the 20th century. Suta's numerous Kāzas (The Wedding) plate compositions vary; now and then the artist inserts new details, yet some others he deletes. It is reminiscent of the kids' game of spotting the difference. Yet dancers, an orchestra, feasting guests, and tables laden with food and drink are always integral to Suta's folk storyline. These paintings have a peculiar, national style and flavour, immanent only to Suta's imagination. However, the figure stylisation and the rhythmic setting come from Cubism.

Suta could have decorated some of the articles, such as the plate Saderināšanās (Engagement), 1927, for the upcoming 1928 exhibition in Tallinn (Fig. 6). Suta's childhood town of Valka shares a border with Valga in Estonia. As a child, he may have studied Estonian folk costumes, and that may be why

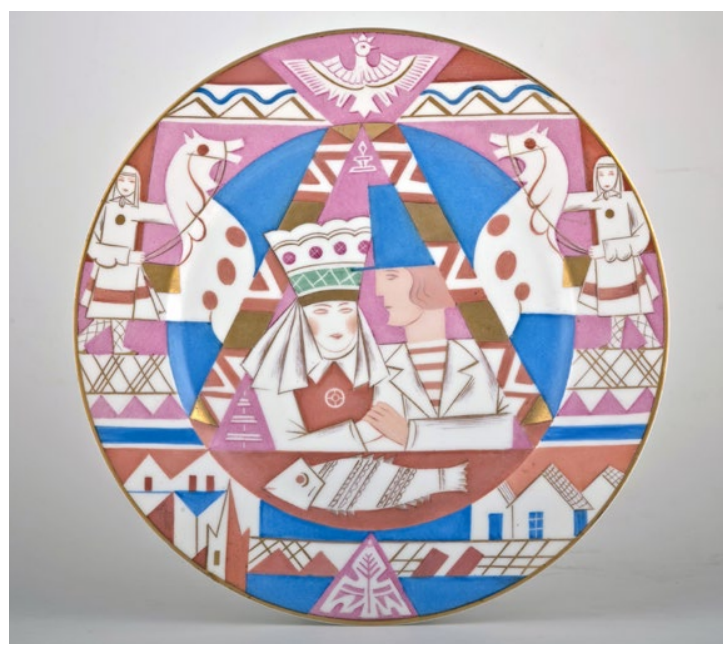

Fig. 6. Romans Suta. Saderināšanās (Engagement). Plate. 1927. Porcelain, overglaze painting, gilding, Ø 25, Pèteris Aven's collection. Photography by Ritvars Skuja women in his works wear folk headdresses that bring to mind the high crowns of Southern Estonia.

His folk festivity paintings-scenes from country fairs and open-air dances-are full of vigour and comical mischief. The merry crowd of dancers and celebrating characters, thoroughly worked out in detail, helps us feel the taste of life and appreciate Suta's artistic ingenuity and humour. Jānis Siliņš draws references, in this respect, to paintings of Pieter Bruegel the Elder (Fig. 7). ${ }^{22}$

Another plate, Deja (The Dance), 1927, is reminiscent of a piece of graphic art painted on porcelain. It is fundamentally different from the above-mentioned plates by the structure of its composition and the application of rotation, stylisation, and ornamentation. For this plate, the artist invented his own border ornament designs, which do not repeat the traditional Latvian ethnographic patterns (Fig. 8).

Suta was always on a quest for new impressions and adventures that he would later transform into creative porcelain designs. Suta's passion for the heroic romanticism of the Latvian past is evident in his painting Kurzeme (Courland), 1927. Applying stylisation typical of Cubist paintings, the artist tells us a 17th-century story of the Duchy of Courland and Jacob Kettler, who conquered the colonies of Tobago and Gambia. Suta's own experience as a soldier during the War of Independence

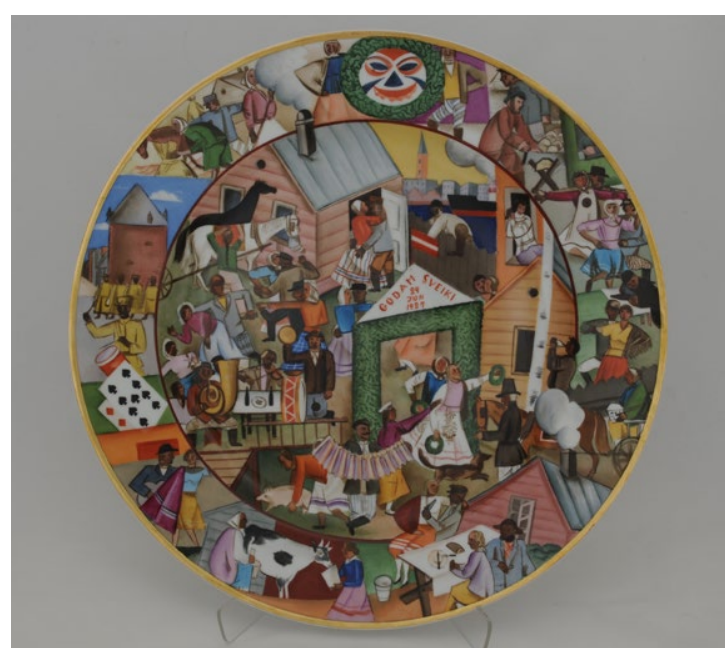

Fig. 7. Romans Suta. Zālu vakars (Eve of the Midsummer Night Festivities). Plate. 1927. Faience, overglaze painting, gilding, Ø 44.3, Museum of Decorative Arts and Design collection, DLM/K-244. Photography by Ritvars Skuja 

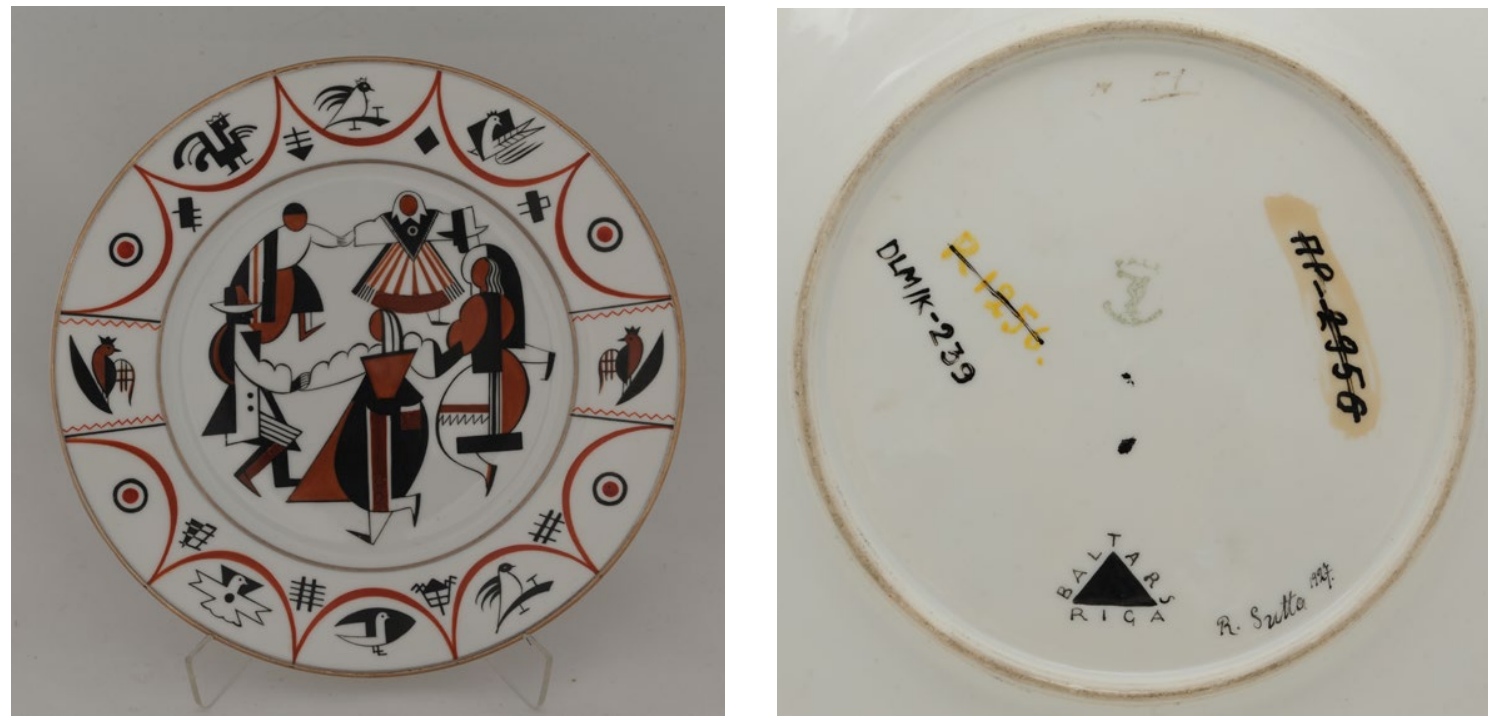

Fig. 8. Romans Suta. Deja (The Dance). Plate. 1927. Porcelain, overglaze painting, gilding, Ø 24.7, Museum of Decorative Arts and Design collection, DLM/K-239. Photography by Ritvars Skuja

finds expression in paintings Div dūjinas (Two Doves), 1926, Bermontiāde (The Bermondt Affair), 1928 (Fig. 9), and Latviešu strēlnieki (The Latvian Riflemen), 1924-1928, and some designs dedicated to this theme. Most probably, they have not survived to this day, and one can only know about them from images published in newspapers and magazines of the past. Most of these paintings are Cubist.

His wife Aleksandra Bel̦cova, Russian by origin, also dedicated her porcelain designs to celebrate Latvian national identity; for example, she made the plate Dziedātājas (Singers), 1925 (Fig. 10), and painted

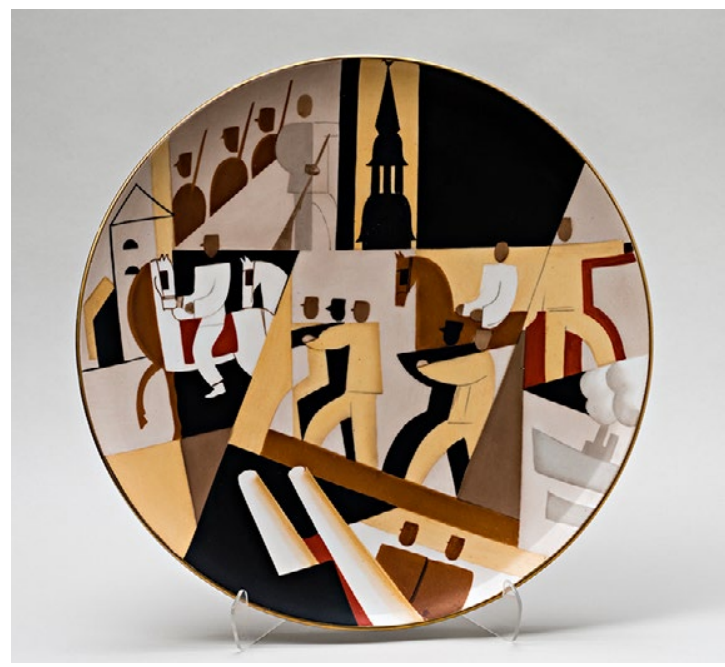

Fig. 9. Romans Suta. Bermontiāde (The Bermondt Affair). Plate. 1928. Porcelain, overglaze painting, gilding, $\varnothing$ 40.5, Museum of Romans Suta and Aleksandra Belcova collection, SB/S-141. Photography by Mārtiņš Lablaiks brooches for the Sixth General Latvian Song Festival of 1926. The topics of her paintings also include festive Russian and Belarusian folk weddings that demonstrate thematic and compositional closeness to the Soviet Russian agitation porcelain ware.

Contrary to Suta, who loved countryside, Vidbergs was an urbanist. The War of Independence and state-building was the subject of his graphic artworks. Likewise, these themes were continued in his porcelain painting designs, although his art is usually associated with the elegant androgynous

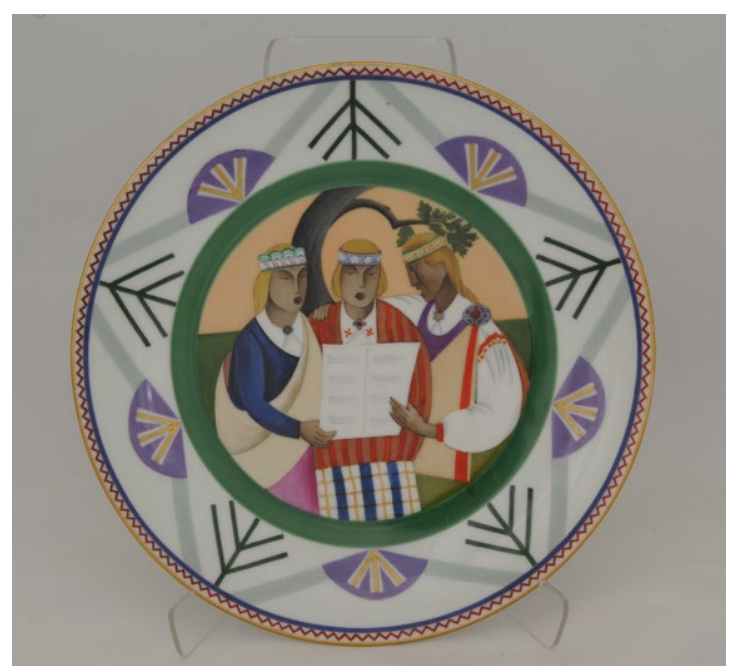

Fig. 10. Aleksandra Beḷcova. Dziedātājas (Singers). Plate. 1925. Porcelain, overglaze painting, gilding, Ø 35, Museum of Decorative Arts and Design collection. DLM/K-133. Photography by Ritvars Skuja 
women in Art Deco surroundings that appear in his illustrations of books, magazines, and newspapers.

The field of porcelain painting was more familiar to him than to Suta and Bel̦cova, as he found glass and porcelain properties quite similar and painted on porcelain with no hesitation. Vidbergs used the surface of porcelain as a white sheet of paper. His hand was masterfully trained and flawless in graphic art, both sketching and drawing. Sometimes his porcelain designs in pen and ink caused surprise and confusion. Artist and art critic Uga Skulme admitted: "Lovely is the porcelain painted by Vidbergs, [but] it is a kind of curiosity as the field of ceramics opens more possibilities for paint and brushwork than for pen and ink." ${ }^{23}$ Zigurds Konstants, an art historian, had an opposite opinion: "In comparison to the other artists of 'Baltars', he [Vidbergs] understood the essence of porcelain more intuitively." ${ }^{24}$

It is generally assumed that two artists-Aubrey Beardsley (1872-1898) and Sergey Chekhonin (1878-1936)-influenced Vidbergs art significantly, especially his early oeuvre. ${ }^{25} \mathrm{He}$ had met Chekhonin in person and this relationship had a stimulating effect. ${ }^{26}$ It is possible to draw parallels between them. Chekhonin and Vidbergs were graphic artists who eventually turned to porcelain painting and were discussing socio-political issues in their artworks. It seems that the paths of both outstanding artists in their quest for creative development ran parallel and without directly affecting each other. $^{27}$

Vidbergs' porcelain paintings are comparable to those of Chekhonin and are respected in the world art scene. The illustrated catalogue of the 1925 Paris International Exhibition of Decorative and Industrial Arts comprises images of the Russian State Porcelain factory products, including Chekhonin's works (awarded a gold medal). Some pages later, we find images of porcelain painted by Vidbergs (Fig. 11). ${ }^{28}$ It seems that the attitude of the catalogue compilers was very reserved and they were reluctant to choose works of foreign artists. Apart from Latvia and Soviet Russia, the catalogue shows porcelain ware images only from eight other countries. The fact that a picture of Vidbergs' porcelain articles (awarded a gold medal) was included in

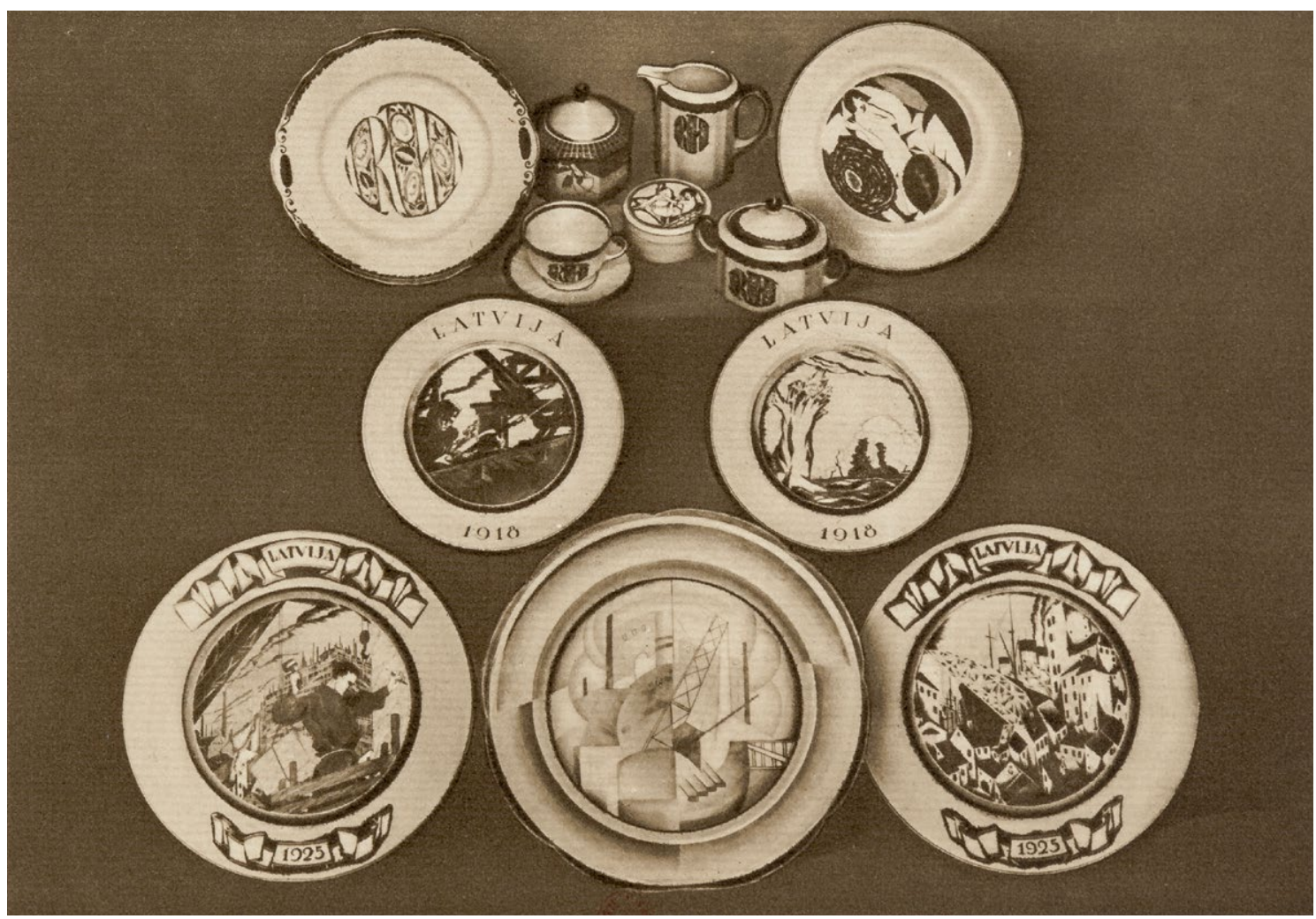

Fig. 11. Sigismunds Vidbergs' plates, exhibited at the 1925 Paris International Decorative and Industrial Arts Exhibition. From the catalogue 
the catalogue is an acknowledgement of his talent. Unfortunately, the number of "Baltars" porcelain items painted by Vidbergs and preserved to this day is small, compared to what is seen in historical material from the 1925 Paris Exhibition display and Latvian periodicals of the time-there were plates, services, cups, saucers, powder boxes.

Vidbergs reached his most powerful expression in 4
2
$\vdots$
$\vdots$
4
-1
0
0
4
0 his works dedicated to the War of Independence and the post-war economic recovery of the Latvian state. In Bermontiāde (The Bermondt Affair)

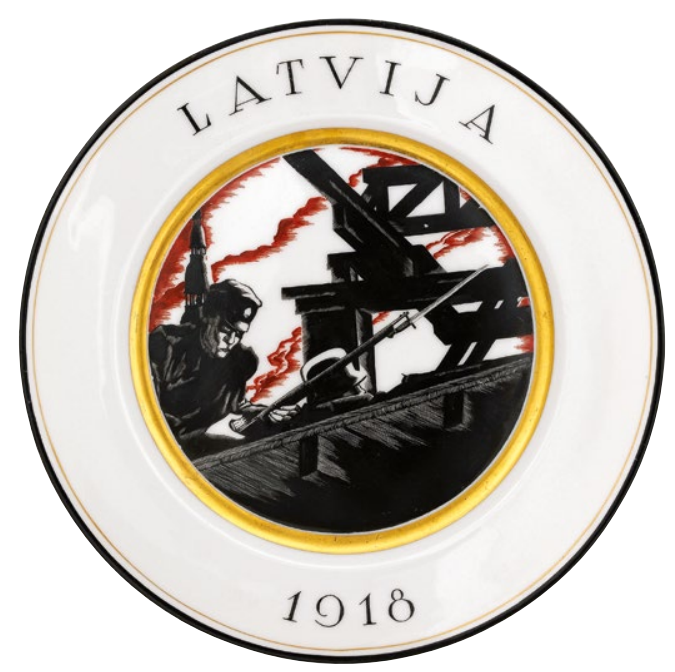

Fig. 12. Sigismunds Vidbergs. Uz Libekas tilta (On the Libeka Bridge). 1925. Porcelain, overglaze painting, gilding, Ø 25.5, Museum of Decorative Arts and Design collection, DLM/K-274. Photography by Ritvars Skuja

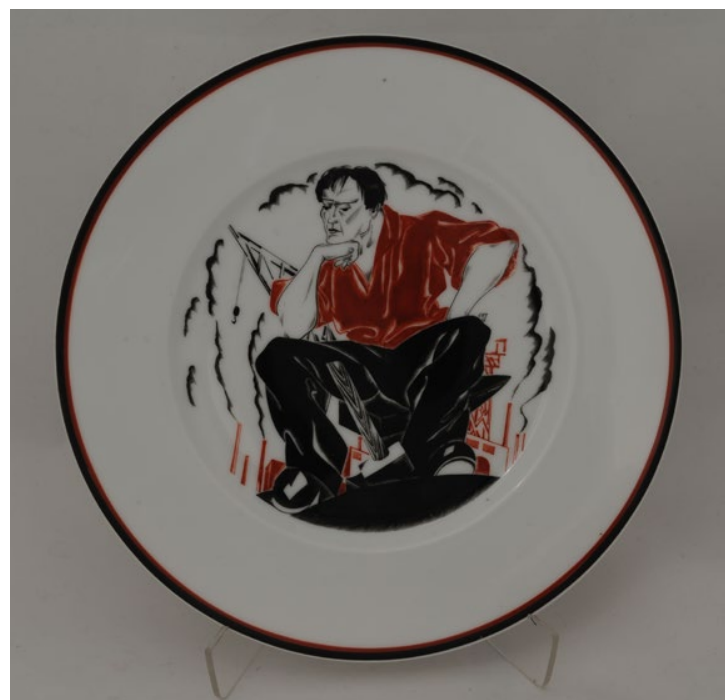

Fig. 14. Sigismunds Vidbergs. Plate. 1925. Porcelain, overglaze painting, gilding, Ø 24.8, Museum of Decorative Arts and Design collection, DLM/K-276. Photography by Ritvars Skuja

series-graphic works and paintings on plateshe reaches emotional catharsis. The heroism of each individual soldier becomes a symbol of the nation's struggle for freedom. The compositions are laconic, based on the contrast of black and white. He unmasks the inhuman nature of war but, at the same time, shows the mighty power of the nation, its will to fight and win. Inspiration for the plates Uz Lìbekas tilta (By the Lìbeka Bridge), 1925, and Daugavmalā. No cikla Bermontiāde (Near Daugava. The Bermondt Affair), 1927 (Fig. 12-13), originates

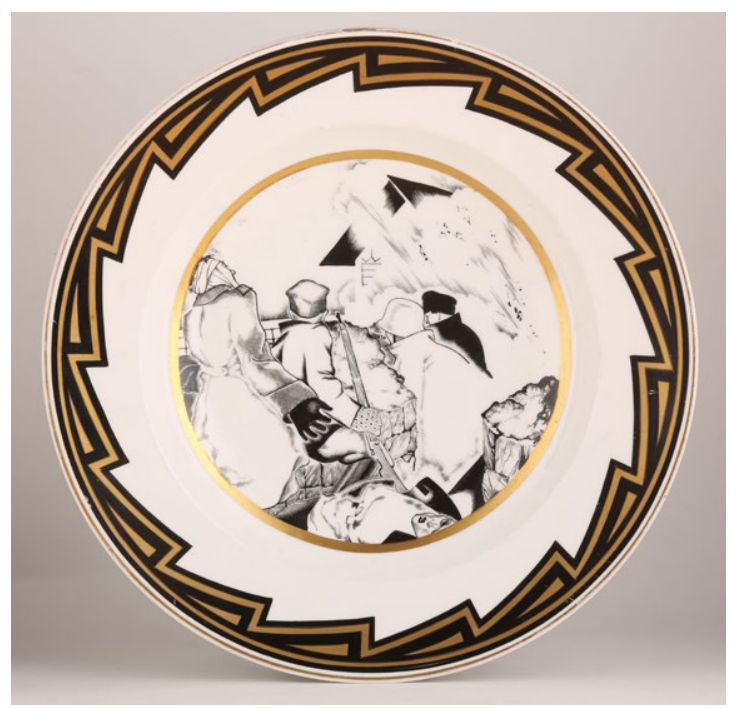

Fig. 13. Sigismunds Vidbergs. Daugavmalā. No cikla Bermontiāde (Near Daugava. The Bermondt Affair). 1927. Porcelain, overglaze painting, gilding, Ø 32.5, Pēteris Aven's collection. Photography by Ritvars Skuja

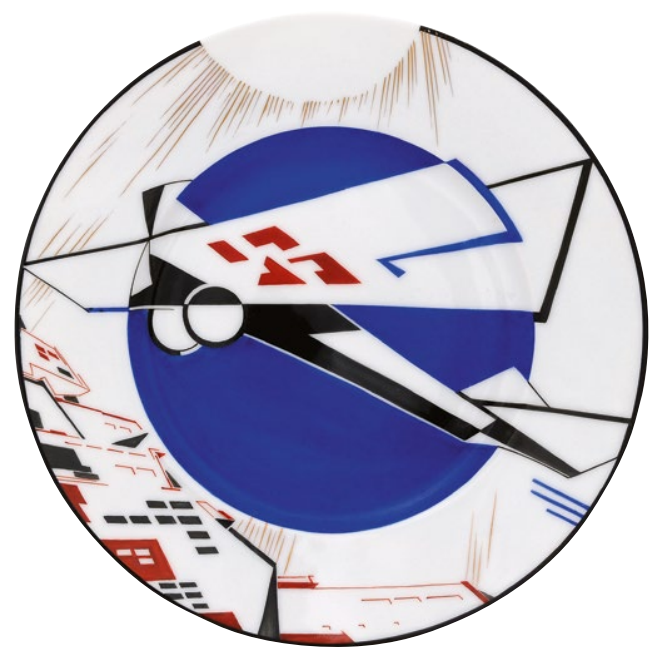

Fig. 15. Sigismunds Vidbergs. Aviācija (Aviation). Plate. 1926. Porcelain, overglaze painting, gilding, Ø 24.9, Museum of Decorative Arts and Design collection, DLM/K-277. Photography by Ritvars Skuja 
in his series of graphic works. The latter plate also features an element much favoured by Art Deco: the border of the plate is decorated with a belt of gold and black triangles reminiscent of saw blades and evokes associations with the ruthless grinding of the war-machine.

In 1926, Vidbergs painted a figure of a worker in an industrial background. It brings to mind the poster he had made in 1925 for the election campaign of the Social Democratic Party. The figure rises like a monument, lost in deep reflection, powerful and creative. This interpretation is close to the topics of the Soviet agitation porcelain paintings (Fig. 14). The plate Aviācija (Aviation), 1926, painted in the Art Deco style, is a song of praise to the modern industrial epoch, its growth, and speed (Fig. 15). The credo of the time was that mechanisation regulated the rhythm of people's lives and was the determining factor of civilisation. Moreover, it tells us a story about Vidbergs' love of piloting aircraft, as piloting was a general infatuation of journalists, artists, and architects in the interwar Latvian society. Aviation was unbelievably popular. Homemade aircraft were being constructed and Latvian aviation industry was starting to develop. ${ }^{29}$

In 1925, after the Paris exhibition, the "Baltars" artists outlined their plans for the future: "As we have already established relevant contacts with Estonian and Lithuanian artists, we shall, in collaboration with them, create works also for Estonia and Lithuania. The ultimate goal of this mutual cooperation will be the foundation of a specific porcelain production industry, common to all three Baltic States, which will manifest the national culture of the Baltic countries." 30

This extract can be defined as an attempt at public diplomacy aimed to promote not only Latvia but also the whole Baltic region.

The syncretic image of public diplomacy had to represent the cultural identity or identities of the Baltic nations in international forums. At that time, the kind of promotion which fosters recognisability was often referred to as "propaganda". Propaganda included participation in international exhibitions and it was a tool of representation. Soviet Russia, as a new country built on the ruins of the Russian Empire, was also interested in introducing itself to the world through propaganda. The task of its art was to promote the new country and its proletarian ideas. In Soviet Russia, agitation porcelain had to be revolutionary in content, complete in shape, and perfect in performance. ${ }^{31}$ In the Latvian press, there are publications in which "Baltars" porcelain is compared with the products of the Russian State Manufactory, that is, agitation porcelain. ${ }^{32}$ From today's point of view, more than just external similarity can be found. The tasks of "Baltars" porcelain were: to introduce the new Latvian state that had never existed before and was unknown to Europe, to tell the world about Latvians, about their nation, ethnography, values, virtue, and human sacrifice in the battles for independence. The innovative creative approach of the artists and decoration of porcelain ware had to prove Latvian taste and technical ability.

In 1926, the "Baltars" artists planned to organise an exhibition in Kaunas. In order to obtain financial support from the Cultural Endowment, they handed in an application form that was stamped with "Baltars/Kaunas-Riga-Tallina." 33 This explained their

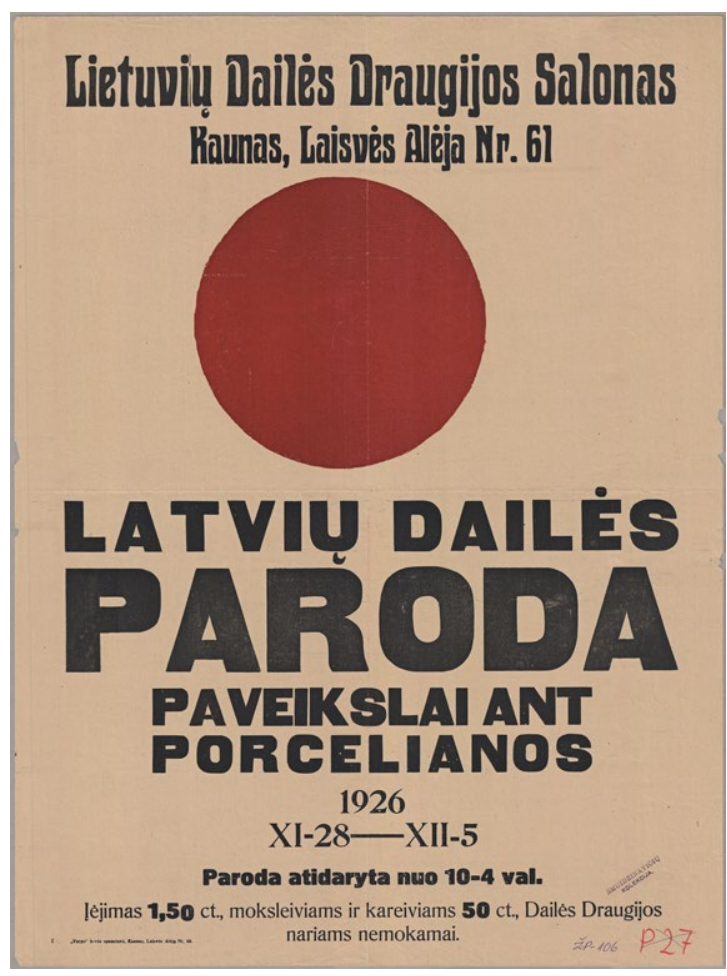

Fig. 16. Poster for the "Baltars" exhibition in the Kaunas Artists' Gallery. 1926. Colour print. Courtesy of Žmuidzinavičius Museum 
plans for exhibition activities in the future. From November 28 to December 5, a vast exhibition of "Baltars" porcelain artworks was opened at the exhibition hall of the Lithuanian Artists Salon in Kaunas, comprising more than a hundred decorated porcelain items (Fig. 16). ${ }^{34}$ There were five participants: Suta, Bel̦cova, Vidbergs, and Lūcija Kuršinska and Šveics, who both worked for the company from time to time. Public acclaim was great, and many artworks were sold. Kazys Grinius, President of the Republic of Lithuania, who had been elected in June, visited the "Baltars" exhibition and bought Bel̦cova's plates Māte (Mother), 1925, and Māte un meita (Mother and Daughter), 1925. World-renowned tenor and Kaunas Opera founder Kipras Petrauskas, who had performed in Riga, Liepāja, and Jelgava, bought four plates: Bel̦cova's Dziedātājas (Singers), 1925, and three plates of Suta's Kāzas (The Wedding), 1925 , series. $^{35}$ (Unfortunately, there is no information about their present location.) After the exhibition, the Čiurlionis Art Gallery kept Suta's plate Käzas (The Wedding), 1926 (Fig. 17), and one of the exhibited brooches. The sales list says that, overall, fourteen porcelain brooches were sold. ${ }^{36}$ In 1978, Elena Žalinkevičaitè-Petrauskienè, Petrauskas' widow, sold one plate designed by Suta to the Mikas and Kipras Petrauskas Lithuanian Music Museum, and this object is still on permanent display there. ${ }^{37}$

The Lithuanian press paid attention to the exhibition and several articles appeared. The most

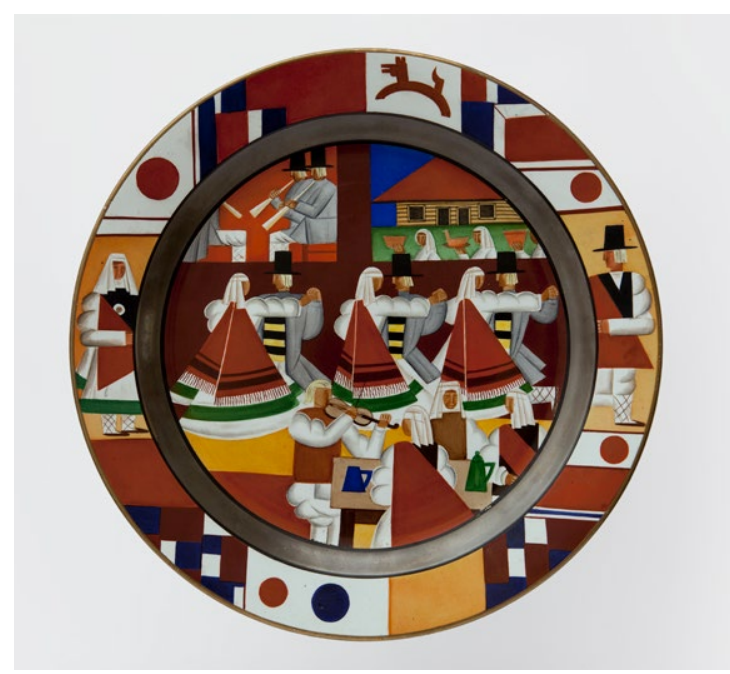

Fig. 17. Romans Suta. Kāzas (Wedding). Plate. 1926. Faience, overglaze painting, silvering Ø 37.8, Tt - 2311. Courtesy of the M. K. Ciurlionis National Museum of Art interesting is the one by Jonas Massačio. He looks at Suta and his art from an unusual point of view, especially when it comes to Suta as theoretician and practitioner of Cubism. Suta's name had already been familiar to Kaunas artists. A year prior to the exhibition, he had delivered a lecture at the Kaunas Art School. Suta had reported on modern art trends and tried to convince the listeners that "only Cubism and others -isms could save art". After the exhibition, the journalist comments: "Unfortunately, Romans Suta proves to be an excellent Cubist only in his theories: his porcelain paintings have little to do with Cubism-its share is as much as a sparrow can bring in its beak.” Massačio claims that he has not seen "any traces of an -ism in Suta's artworks". In his opinion, Suta is skilful at stylisation, but some of his works are over-stylised, although he keeps on following the right direction. It seems that the journalist has mixed up styles: in the next paragraph, for comparison, he characterises an example, as it might seem, of surrealistic painting he had seen somewhere abroad. Meanwhile, he praises Bel̦cova for her poetic picture of the world, as well as Šveics and Vidbergs, stressing that the latter is an outstanding illustrator of books. In conclusion, the journalist expresses his hope that, after the successful exhibition of Latvian artists' porcelain painting, local artists will finally start thinking about their role in the advancement of porcelain industry in Lithuania. ${ }^{38}$

Another "Baltars" exhibition in 1928, as the artists had envisaged, was organised at the Tallinn Art School and was running from April 1 to April 15 (Fig. 18). ${ }^{39}$ Its participants were Suta, Bel̦cova, and students of Suta's studio of porcelain painting. Vidbergs at the time had already left "Baltars" for "Burtnieks", the newly-opened porcelain painting workshop that was established in 1929 by the Benjamiñš family of press magnates and was a rival to "Baltars", for "Burtnieks" production was more accessible and cheaper. The Estonian press published some reviews of the exhibition and pointed out that professional painting of ceramics at the time was not so wellknown in Estonia and that the achievements of Latvians were very respectable and "allow[ed] them to proudly display their art abroad" ${ }^{40}$ 


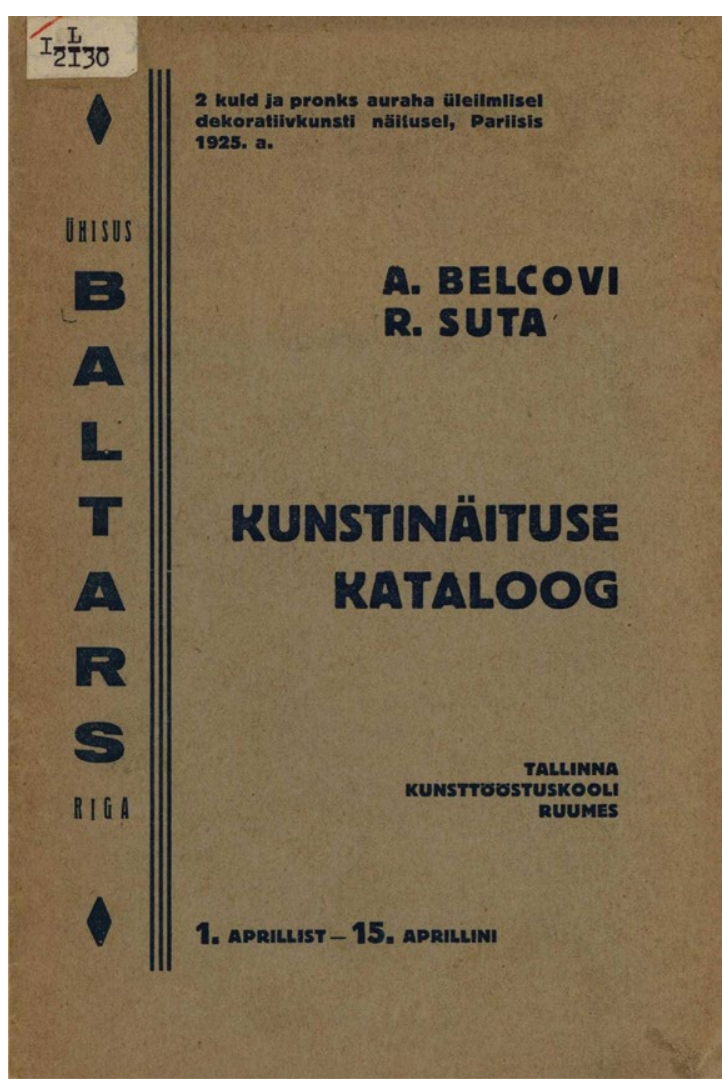

Fig. 18. "Baltars" catalogue for the exhibition in Tallinn. 1928

After the exhibition, nine porcelain items remained in Estonia. In 1979, the State Art Museum of the Latvian SSR brought "Baltars" porcelain ware back home through mutual artwork exchange. In turn, the Estonian artist August Weizenberg's (18311921) marble sculpture which till then was kept at the Latvian museum was given back to Estonia. This initiative was invaluable in respect of art preservation, promotion of Latvian history of art, and its public accessibility.

In 1930, "Baltars" porcelain paintings were included in the exhibition organised by the Riga Artists Group at the Karlstad Museum, Sweden. ${ }^{41}$ Suta and Belcova sold several plates and received a private commission for another six. Photos of exhibits, price tags, and documents regarding this are still kept in the archive of the museum. Unfortunately, there is no information if Suta had ever painted the commissioned plates, because it was the time when "Baltars" gradually started to wind up its activities. In 1930, Pelše included "Baltars" plates in a ceramic artwork donation of the Republic of Latvia to the National Museum of Ceramics in Sevres. ${ }^{42}$ At present, the museum keeps one plate by Belcova and four plates by Suta, including two Wedding plates. There is also information on a possibility that one plate by Vidbergs could still be in the museum's storage, as it was on the donation list. Unfortunately, due to the bombing of Paris by the Allies in 1943, some objects of the Latvian collection were damaged or have disappeared.

There are various assumptions considering the closing date of the workshop. Some researchers assert that "Baltars" ceased its activities or even went bankrupt in 1928; others indicate that it happened in 1929, although its exhibition activities continued in 1930. Strangely enough, even concrete dates are mentioned without any reference to archival sources. ${ }^{43}$ The press of the time has it clear that property belonging to Ozolina-Krauze had been sold in two auctions already in 1926 and in $1927 .{ }^{44}$ In the first case, it was some furniture sold for a small amount of money, and some books and a woman's watch in the second. ${ }^{45}$ These financial problems cannot be perceived as bankruptcy. Did this financial situation have any impact on the lifestyles of Belcova and Ozolina-Krauze? The magazine Ekonomists (The Economist) reports that, already on December 30, 1929, a trading and industrial joint-stock company Piena Eksports (Milk Export) with a share capital of a hundred thousand lats was established. In the list of its five shareholders, we can spot Aleksandra Mitrofan's daughter Suta, better known as Aleksandra Belcova-Suta. ${ }^{46}$ Judging from the press, both friends, despite their "bankruptcy", were going to spend the period from autumn 1929 to spring 1930 in Nice, France, just like the year before. ${ }^{47}$ Some researchers are convinced that the world economic crisis that began in 1929 in the USA was the reason that the workshop stopped its activities, but this is hardly true..$^{48}$ It is possible that this statement could be the result of the Soviet time socialist teachings of political economy and reflects the understanding of economic processes at that time. The economic crisis in the USA started only in October 1929 and was never able to retrospectively influence Latvian economy. Of course, the global economic crisis affected life in Latvia and hit the cultural and art scene hard. Historians associate the economic crisis 
in Latvia with the period from 1930 to 1934. Economist Arnolds Aizsilnieks writes: "Latvia began to experience the winds of economic depression in 1930. They started with a gradual drop of prices, especially in the second half of the year and for the most important Latvian export goods." ${ }^{49}$ Competition also played a significant role in the fate of "Baltars", because in 1929 the above mentioned porcelain-painting workshop "Burtnieks" was founded by the Benjaminš family of wealthy Riga entrepreneurs. They advertised their new production in their publications of great circulation and generously paid artists and art students for porcelain ware designs. ${ }^{50}$ Since "Baltars" crockery was too expensive for an average buyer, mostly only the upper middle class-lawyers, diplomats, doctors, art collectors, etc. - could buy it. Another factor that determined the demise of "Baltars" activities could be the frequent disagreements of personal character, which definitely played a crucial role when Vidbergs and Abrosimov decided to leave for the new company. Suta's intolerant and enthusiastic character also contributed to the closure of "Baltars". He loved everything that was new and unexplored and was eager to try and implement new projects. Suta's artistic activities were diverse: besides engaging in oil painting, graphic art, scenography, painting on glass, interior design, organisation of exhibitions, and design projects for exhibition pavilions, he was also a hyperactive public figure that held lectures and wrote for the press on various issues of art and culture. He loved to take up challenges and activities and saw his life as an art performance. For "Baltars" to be efficient, a solid state sponsorship and many marketing strategies that we know today would have been necessary. Suta was not a businessperson as he cared only for art. However, despite the commercial failure in porcelain production, Suta still cherished the idea to elaborate a contemporary ideology for the advancement of Latvian art. In January 1930, the "Baltars" workshop opened its doors to a meeting of artists interested in the foundation of the Art Discussion Club. ${ }^{51}$ Finally, the closure of "Baltars" took place only on July 3, 1931, and a newspaper reporter told the readers the following: "The nice company of artists who used to stick together has split, each in different direction, and their place at Lāčplēša Street has been closed down for good." 52

\section{CONCLUSIONS}

In the 1920s, Latvian applied art, including ceramics, was considered controversial-some believed that everything was developing in the right direction or, as the press called it, "in a peculiar national style", without worrying about contemporary requirements, styles, and fashion. There was an opposition to this, and one of its leaders was modernist Romans Suta, always ready for a challenge, and foundation of the "Baltars" porcelain-painting workshop was one of them. Already from the first day, he had planned to encompass Lithuania and Estonia in his creative porcelain production plans and eventually formulated the idea of building a joint artistic ware-production industry, the produce of which, in his opinion, would demonstrate the visual culture and accomplishments of the Baltic nations. Yet his intentions did not find any resonance in Estonia or Lithuania. This surely was a premature project for the time. "Baltars" definitely was a unique company as there is no evidence of any similar workshops operating in European countries. They won great acclaim internationally because they were different, and their only rivals were the Soviet Russian revolutionary propaganda porcelain artists and their art. The 1925 Paris Exhibition awards proved that the "Baltars" artists had a lot of creative potential, which, unfortunately, was not used in full. Nevertheless, the "Baltars" phenomenon had a tremendous impact on porcelain painting traditions in Latvia.

\section{References}

Aizsilnieks, Arnolds. Latvijas saimniecības vēsture, 19141945. Stokholma: Daugava, 1968-1976.

“Baltarsi näitus." TAIE Eeesti Kunst Ajakiri, Nr. 2, 1928, 101-102.

Baranovska, Inese, et al., eds. Rigas mākslas porcelāns = Rizhskii khudozhestvennyi farfor = Riga's Porcelain Art: 1925-1940. Riga: Latvian National Museum of Art, 2012.

Bērziņa, Marita. Sigismunds Vidbergs. Rīga: Neputns, 2015. 
Brasliņa, Aija. "Kaimiņu attiecības. Latvijas un Igaunijas mākslu sakari starpkaru periodā.” In Muzeja raksti Nr. 5. Rīga: Latvijas Nacionālais mākslas muzejs, 2014.

Brasliņa, Aija. "Starptautiskie sakari Latvijas klasiskā modernisma pacēluma un jaunreālisma veidošanās posmä" ("International Connections during the Rise of Latvian Classical Modernism and the Formative Period of Neorealism"). PhD diss., Art Academy of Latvia, 2016.

Erste russische Kunstausstellung, Berlin, 1922, Galerie Van Diemen \& Co. Foreword by D. Shterenberg, Redslob, and A. Holitscher. Berlin: Internationale Arbeiterhilfe, 1922.

Exposition internationale des arts décoratifs et industriels modernes, Paris, 1925: rapport général: [section artistique et technique. Volume V. Accessoires du mobilier, Classes 9 à 12]. Paris: Libraire Larousse, 1927.

Jevsejeva, Natālija. Aleksandra Beḷcova. Rīga: Neputns, 2014.

Kḷaviņš, Eduards, ed. Art History of Latvia: Period of Classical Modernism and Traditionalism: 1915-1940. Riga: Institute of Art History of the Latvian Academy of Art, 2016.

Konstants, Zigurds. Baltars. Rīga: Latvijas enciklopēdija, 1996.

Konstants, Zigurds. "Elements of Cubism in the porcelain and faience paintings of the 'Baltars' workshop." In Cubism in Latvian Art. Rīga: Neputns, 2002.

Konstants, Zigurds, and Taisija Poluikeviča. Rīgas porcelāns un fajanss. Rīga: Zinātne, 1984.

Krastiņš, Edmunds. Latvijas rūpniecība XIX-XXI gadsimtā: vēsturiski ekonomiska apcere. Rīga: Jumava, 2018.

Lamberga, Dace. "Baltars fenomens." In Romans Suta, edited by Laima Slava. Rìga: Neputns, 2016.

Latvijos dailes paroda. Paveikslai ant porcelianos 1926. Lietuvių dailès draugija: 1926.

"Läti kunstinäitusest Tallinnas," Waba Maa, Nr. 84, 1928.

Liepiņš, Oḷgerts. Sigismunds Vidbergs. Rīga: K. Rasiṇa apgāds, 1942.

"Māksla." Aizkulises, Nr. 50, December 18, 1929, 4.

"Māksla." Laikmets, Nr. 15, November 18, 1924.

Massačio, Jonas. "Latvių dailininkų paroda Kaune." Lietuvos žinios, December 4, 1926.

"Mūsu mākslas propaganda ārzemēs. Zviedru interese par mūsu glezniecibu." Latvijas Kareivis, Nr. 100, 6 May, 1930.

Neimiševa, Ludmila. Darbnīca "Baltars". Rīga: Neputns, 2017.

Pelše, Rūdolfs. "Keramika Latvijā un pie citām tautām." Ritums, Nr. 9, 1923, 705.

"S. Vidberga izstāde." Aizkulises, Nr. 18, May 7, 1926, 8.

Scott, Paul. Painted Clay: Graphic Arts and Ceramic Surface. London: Watson-Guptill Publications, 2001.

Siliņš, Jānis. "Latviešu lietiškās mākslas izstāde." Izglìtības Ministrijas Mēnešraksts, Nr. 6, 1924, 677.

Siliņš, Jānis. Latvijas māksla 1915-1940. Stokholma: Daugava, 1988

Siliņš, M. "Kooperacijas dienas Beḷgijāa”." Kopdarbība, Nr. 48, 29. 11. 1924.

Skulme, Uga. “Trīs izstādes." Izglītības Ministrijas Mēnešraksts, Nr. 4, April 1, 1938, 513.
Suta, Romans. "Nacionālā māksla." Domas, Nr. 5, 1924 , 464.

Suta, Tatjana. Romans Suta. Rīga: Latvijas enciklopēdija, 1996.

Suta, Tatjana. Romans Suta. Rīga: Liesma, 1975.

Šmits, Uldis. "Daži dokumetāli papildinājumi latviešu mākslas izstāžu aizkulisēm Parīzē. Trīsdesmitie gadi." Literatūra un Māksla, April 29, 1989.

Viese, Saulcerīe. Mūžìgie spārni. Rīga: Jaunā Daugava, 2004.

Warchałowski, Jerzy. Polska sztuka dekoracyjna. Warszawa-Kraków: Wydawnictwo J. Mortkowicza, 1928.

Констант, 3. Ф. "Возникновение латышского художественног фарфора.” Известия Академии Наук Латвийской ССР. Но. 7 (384), 1979, 71-72.

\section{Notes}

1 National Foundation on the Arts and the Humanities Act Media Kit, 1965. http://www.lbjlibrary.org/mediakits/ neaneh/

2 Rigas mākslas porcelāns = Rizhskii khudozhestvennyi farfor = Riga's porcelain art: 1925-1940, ed. Inese Baranovska (Riga: Latvian National Museum of Art, 2012), 311; Marita Bērziņa, Sigismunds Vidbergs (Rīga: Neputns, 2015); Aija Brasliņa, "Starptautiskie sakari Latvijas klasiskā modernisma pacēluma un jaunreālisma veidošanās posmā" ("International Connections during the Rise of Latvian Classical Modernism and the Formative Period of Neorealism"), (PhD diss., Art Academy of Latvia, 2016); Natālija Jevsejeva, Aleksandra Belcova (Rīga: Neputns, 2014); Art History of Latvia: Period of Classical Modernism and Traditionalism: 1915-1940, ed. Eduards Kḷaviņš (Riga: Institute of Art History of the Latvian Academy of Art, 2016); Dace Lamberga, "Baltars fenomens" in Romans Suta, ed. Laima Slava (Rīga: Neputns, 2016), 303-305; Ludmila Neimiševa, Darbnīca "Baltars" (Rīga: Neputns, 2017).

3 Do. "Stilistiskākā jaunbūve Rīgā." Nedēḷa, Nr. 39 (26.09.1924), 17.

4 Vemblejas izstāde Ilustrēts Žurnāls, Nr. 23 (06.06.1924), 506-507.

5 M. Siliņ̌̌, "Kooperacijas dienas Beḷgijā," Kopdarbība, Nr. 48 (29.11.1924), 795.

6 Jānis Silin̦š, "Latviešu lietišḳās mākslas izstāde,"

Izglìtības Ministrijas Mēnešraksts, Nr. 6, 1924, 677.

7 Romans Suta, "Nacionālā māksla," Domas, Nr. 5, 1924, 464.

8 Ibid., 465.

9 Rūdolfs Pelše, "Keramika Latvijā un pie citām tautām," Ritums, Nr. 9, 1923, 705.

10 Ibid., 705-706.

11 Erste russische Kunstausstellung, Berlin, 1922, Galerie Van Diemen \& Co., forew. D. Shterenberg, Redslob, and A. Holitscher (Berlin: Internationale Arbeiterhilfe, 1922), 31.

12 Jerzy Warchałowski, Polska sztuka dekoracyjna (Warszawa-Kraków: Wydawnictwo J. Mortkowicza, 1928), 14.

13 Tatjana Suta, Romans Suta (Rīga: Latvijas enciklopēdija, 1996), 46.

14 "Māksla," Laikmets. Nr. 15, November 18, 1924.

15 3. Ф. Констант, “Возникновение латышского художественног фарфора,” Известия Академии Наук Латвийской ССР. Но. 7 (384), 1979, 71-72; Zigurds 
Konstants and Taisija Poluikeviča, Rīgas porcelāns un fajanss (Rīga: Zinātne, 1984), 38.

16 Latvian State Historical Archive LVVA, 1655. f. 1, apr. 1866. 1., 1.

17 Saulcerīte Viese, Mūžīgie spārni (Rīga: Jaunā Daugava, 2004), 442-443; Bonifācijs Daukšts, "Politiskās biogrāiijas epizodes," Latvijas Jaunatne, 1990.12.13.

18 The owner of the house was not Austra Ozolina-Krauze, it belonged to her mother Anna Ozoliņa.

19 Romans Suta and Aleksandra Beḷcova Museum SB/D 972, LNMM SBM; SB/D 1250 LNMM SBM; “Tirdzniecības un rūpniecības akciju sabiedrības „Piena eksports" statūti," Ekonomists, Nr. 5, March 1, 1930, 221.

20 Exposition internationale des arts décoratifs et industriels modernes, Paris, 1925: rapport général: [section artistique et technique. Volume V. Accessoires du mobilier, Classes 9 à 12]. Paris: Libraire Larousse, 1927, Pl. XXVII; LXXVI.

21 Biruta Senkēviča, Latviešu ǵimenes godi (Cicero, Illinois, 1957).

22 Jānis Siliň̦̌, Latvijas māksla 1915-1940 (Stokholma: Daugava, 1988), 234

23 Uga Skulme, "Trīs izstādes," Izglītības Ministrijas Mēnešraksts. Nr. 4, April 1, 1938, 513.

24 Zigurds Konstants, Baltars (Rīga: Latvijas enciklopēdija, 1996), 23.

25 Oḷgerts Liepiņš, Sigismunds Vidbergs (Rīga: K. Rasiņa apgāds, 1942); Marita Bērziṇa, Sigismunds Vidbergs (Rīga: Neputns, 2015), 18.

26 "S. Vidberga izstāde," Aizkulises. Nr. 18, May 7, 1926, 8.

27 Oḷgerts Liepiņš, Sigismunds Vidbergs (Rīga: K. Rasiṇa apgāds, 1942), 11.

${ }_{28}$ Exposition internationale des arts décoratifs et industriels modernes, Paris, 1925.

29 R. Celms, "Latvijas pirmā sporta lidmašina 'Sprīinitis", Sporta Žurnāls, Nr. 15, April 11, 1924, 3. "Latvijā būvēta lidmašina," Latvijas Kareivis, Nr. 219, September 29, 1927, 3.

30 Aija Braslina, "Kaiminu attiecibas. Latvijas un Igaunijas mākslu sakari starpkaru periodā" in Muzeja raksti Nr. 5 (Rīga: Latvijas Nacionālais mākslas muzejs, 2014), 119-130.

31 Фарфор 1917-1925 гг. http://www. hermitagemuseum.org/wps/portal/hermitage/explore/ collections/master/sub/1252763710/?lng=ru\&\%27nde?p 1=room:B30_F2_H221

32 "Māksla," Aizkulises, Nr. 26, July 2, 1926, 5.

Paul Scott, Painted Clay: Graphic Arts and Ceramic Surface (London: Watson-Guptill Publications, 2001), 43-53. 33 Latvian State Historical Archive LVVA, 1632. f. 3, apr. 855, 13-16.

34 Latvijos dailess paroda. Paveikslai ant porcelianos 1926 (Lietuvių dailès draugija, 1926).

35 Romans Suta and Aleksandra Bel̦cova Museum SB/D 973, LNMM SBM.
36 Ibid., 706.

37 The above-mentioned plate and one of the brooches are in the collection of the M. K. Čiurlionis Museum of Art. In Kaunas, only one plate by Suta is on display at the Kipras and Mikas Petrauskas Lithuanian Music Museum. 38 Jonas Massačio, "Latvių dailininkų paroda Kaune," Lietuvos žinios, December 4, 1926, 4.

39 Waba Maa, Nr. 84, 1928, 8.; "Läti kunstinäitusest Tallinnas," Postimees, Nr. 104, 1928, 4.

40 “'Baltarsi”" näitus," TAIE Eeesti Kunst Ajakiri, Nr. 2, 1928, 101-102.

${ }^{41}$ "Mūsu mākslas propaganda ārzemēs. Zviedru interese par mūsu glezniecību," Latvijas Kareivis, Nr. 100, May 6, 1930, 3 .

42 Uldis Šmits, "Daži dokumetāli papildinājumi latviešu mākslas izstāžu aizkulisēm Parīzē. Trīsdesmitie gadi," Literatūra un Māksla, 29 April, 1989.

43 Zigurds Konstants, "Elements of Cubism in the porcelain and faience paintings of the "Baltars' workshop" in Cubism in Latvian Art (Rìga: Neputns, 2002), 126.

3. Ф. Констант, “Возникновение латышского художественног фарфора,” Известия Академии Наук Латвийской ССР. Нo. 7 (384), 1979, 71-72. Ludmila Neimiševa, Darbnīca "Baltars" (Rīga: Neputns, 2017), 38.

Rūta Rinka, "Lietišķā māksla" in Art History of Latvia: Period of Classical Modernism and Traditionalism: 19151940. (Riga: Institute of Art History of the Latvian Academy of Art, 2016), 580.

Dace Lamberga, "Baltars fenomens" in Romans Suta, ed. Laima Slava (Rīga: Neputns, 2016), 303. Ludmila Neimiševa, "Darbnīcas 'Baltars' porcelāns" in Rigas mākslas porcelāns $=$ Rizhskii khudozhestvennyi farfor $=$ Riga's porcelain art: 1925-1940 (Riga: Latvian National Museum of Art, 2012), 40.

Tatjana Suta, Romans Suta (Rīga: Liesma, 1975), 57.

44 “Tiesu sludinājumi," Valdības Vēstnesis, Nr. 122, June 5, 1926, 4. “Tiesu sludinājumi," Valdības Vēstnesis, Nr. 83, April 27, 1927, 4.

45 The value of sold objects amounted to a four-month wage of a qualified worker. Arnolds Aizsilnieks, Latvijas saimniecības vēsture, 1914-1945 (Stokholma: Daugava, 1968-1976), 401.

46 "Tirdzniecỉbas un rūpniecības akciju sabiedrības 'Piena eksports' statūti,' Ekonomists, Nr. 5, March 1, 1930, 221.

47 “Die Oberen Zweitausend," Elegantā Riga, Nr. 1, January $1,1930,8$.

48 Konstants and Poluikeviča, 38.

49 Edmunds Krastiņš, Latvijas rūpniecība XIX-XXI gadsimtā : vēsturiski ekonomiska apcere (Rīga: Jumava, 2018), 93; Aizsilnieks, 440.

50 “Māksla," Aizkulises, Nr. 50, December 18, 1929, 4.

51 "Jauna mākslinieku organizācija," Pēdèjā brìdī, Nr. 9, January 6, 1930, 12.

52 "Māksla," Aizkulises, Nr. 27, July 3, 1931, 3. 
Dace L,AVIN̦A

Latvijos meno akademija, Ryga, Latvija

\section{NACIONALINĖS TAPATYBE்S IR MODERNIZACIJOS SIMBIOZE் DIRBTUVÉS „BALTARS“(„BALTŲ MENAS“) 1924-1930 METŲ PALIKIME}

\section{Santrauka}

Straipsnyje analizuojama kolektyvinès dirbtuvès „Baltars“, gaminusios tapytus porceliano gaminius, veikla 19241930 metais. Pažymėtina, jog šią dirbtuvę Rygoje įkūrè trys menininkai modernistai: tapytojai Romanas Suta (1896-1944), Aleksandra Beḷcova (1892-1981) ir grafikos menininkas Sigismundas Vidbergas (1890-1970). „Baltars“ fenomenas reikšmingas dèl menininkų išrastų inovacijų, pritaikytų Latvijos porceliano gamyboje, bei Latvijos porceliano gaminių parodų 1920-aisiais ir 1930-aisiais tiek vietiniame Latvijos kontekste, tiek Baltijos jūros regione (Lietuva, Estija, Švedija).

Šiame straipsnyje analizuojamas „Baltars“ dirbtuvès įkūrimas ir uždarymas, kompanijos meninė veikla, pastangos įsilieti ị platesnị tarptautinị meno ir prekybos kontekstą bei dirbtuvès laimèjimai. Pažymètina, jog gausios parodos ir publikacijos paskatino didesnį susidomėjimą Latvijos porceliano menu, tad diskursas apie „Baltars“ fenomeną tapo itin aktualus. Dèl išaugusio susidomèjimo šiuo menu taip pat kyla nemažai klausimų, susijusių su modernizacija, jos itaka menui, nacionalizmu, nepriklausomos valstybės manifestacija. Tad šiame tekste taip pat bus analizuojamos ir šios tematikos, demonstruojamos ištapytose scenose ant porceliano dirbinių.

Reikšminiai žodžiai: „Baltars“ dirbtuve, Ryga, tapyba ant porceliano gaminių, revoliucinè propaganda, tautinè tapatybè, tarptautinès parodos.

Gauta 2019-03-31

Parengta spaudai 2019-08-07

\section{Dace L,AVIN̦A}

PhD student, Art Academy of Latvia, Riga, Latvia

E-mail: dace.lavina@gmail.com 